\title{
Evaluation of a voluntary augmented reality nutrition menu labelling application (Nutrilabelapps $($ ) ) usage in a university café: a cross-sectional study in Terengganu, Malaysia
}

\author{
${ }^{1}$ Zulkifli, N.F.A., ${ }^{1, *}$ Asma', A. ${ }^{1}$ Yusof, H.M., ${ }^{1}$ Khairil-Shazmin, K., ${ }^{1}$ Zakaria, N.S., \\ ${ }^{2}$ Mustafa, M. and ${ }^{3}$ Mhd Jalil, A.M. \\ ${ }^{1}$ Faculty of Fisheries and Food Science, Universiti Malaysia Terengganu (UMT), 21030 Kuala Nerus, \\ Terengganu Darul Iman, Malaysia \\ ${ }^{2}$ Faculty of Ocean Engineering Technology and Informatics, Universiti Malaysia Terengganu, 21030 Kuala \\ Nerus, Terengganu Darul Iman, Malaysia \\ ${ }^{3}$ School of Nutrition and Dietetics, Faculty of Health Sciences, UniSZA, Gong Badak, 21300 Kuala Nerus, \\ Terengganu Darul Iman, Malaysia
}

\author{
Article history: \\ Received: 29 June 2020 \\ Received in revised form: 8 \\ August 2020 \\ Accepted: 2 September 2020 \\ Available Online: 1 \\ November 2020
}

Keywords:

Nutrition menu labelling,

Knowledge,

Attitude,

Feasibility,

Acceptability,

Malaysia

DOI:

https://doi.org/10.26656/fr.2017.4(6).313

\begin{abstract}
Nutrilabelapps $\mathbb{C}$ is an interactive augmented reality mobile application (app) providing nutrition menu labelling specifically built for Mutiara Café, a café in Universiti Malaysia Terengganu. However, no evaluation of the usage of Nutrilabelapps $\subset$ has been carried out. Therefore, this cross-sectional study was aimed to determine the knowledge and attitude of nutrition menu labelling among Mutiara Café customers; the feasibility and acceptability of the app among customers; and also, the relationships between knowledge, attitude, feasibility and acceptability of this augmented reality nutrition menu labelling app. This study was conducted among 108 Mutiara Café customers who owned a smartphone and were able to download the Nutrilabelapps $\mathbb{C}$. The data were analyzed using SPSS version 25. Findings showed that only $4.6 \%$ of Mutiara Café customers had good knowledge of nutrition menu labelling, while $71.3 \%$ of them had a positive attitude towards nutrition menu labelling. Nutrilabelapps $(\subset$ was accepted by users based on the feasibility $(67.6 \%)$ and acceptability $(75.9 \%)$ of the app. Remarkably, there was a significant association between knowledge, attitude, feasibility, and acceptability of the app at $\mathrm{p}<0.05$. As a conclusion, Nutrilabelapps $\bigcirc$ is highly recommended among the café customer despite their low knowledge of the nutrition menu labelling. Therefore, more education of the public about nutrition menu labelling is highly recommended.
\end{abstract}

\section{Introduction}

Nutrition menu labelling is imperative, as it will guide customers in selecting a healthier choice or at least allow awareness of their nutritional value needs. It is crucial for Malaysia to implement this menu labelling as the trend of consumption of food-away-from-home (FAFH) consumption has dramatically increased. The Department of Statistics Malaysia (2015) has stated that family from all income classes do allocate a portion of their monthly income to FAFH. The statistic showed that families with household incomes of RM8,000 to RM10,000 spend the highest expenditure on FAFH $(4.5 \%)$, while those with household income about RM3,000 to RM5,000 spend about $3.4 \%$ on FAFH. Few restaurants in Malaysia have taken the initiative to voluntary display the menu labelling in their restaurant but it turns to be highly neglected by customer. As reported by the Institute for Public Health (2017), 15.5\% of Malaysian adolescence does not read the menu labelling during food purchasing. One of the possible factors is may be due to its appearance that may be less unattractive (van der Laan et al., 2012). Another possible reason is maybe due to a lack of knowledge among the customer. Customer will tend to not ignore the menu labelling if they have adequate knowledge of how to interpret the nutrition information stated (Radwan et al., 2017).

Previously, a study on the impact of icon-based menu labelling on customer behaviour was done where menu items with low fat, sugar and fibre were referred to as 'heart healthy'. Unfortunately, there has been no relationship found between healthy labels on menu items with customer's food choices (Kerins et al., 2016). In another study, a program known as the Informed Dining 
Program (IDP) was implemented to assess customer's awareness of nutrition information in the restaurant before and after ordering. It was carried out to promote healthy food choice, but the results showed that there were no significant changes among customers' eating habits (Vanderlee et al., 2019).

Thus, to create awareness of nutritional menu labelling among customers, the Nutrilabelapps $(\subset$ mobile application (app) was developed by researchers at Universiti Malaysia Terengganu. This app is an interactive approach via augmented reality to display the nutritional information of the food at the Mutiara Café in Universiti Malaysia Terengganu. This newly developed app is in line with the 4th Industrial Revolution, as the customer will be able to access conveniently the nutritional information such as calories, energy, carbohydrate, protein and fat of cooked food available at the café since the cooked food does not have packaging that shows the nutritional information. The app is easy and free to be downloaded in the Google Play store (https://play.google.com/store/apps/details? $\mathrm{id}=$ com.Farez.MutiaraCafeandhl=en).

Therefore, this study will determine the knowledge and attitude of menu labelling usage among customer and evaluate the feasibility and acceptability of this Nutrilabelapps $($ application among the customers of Mutiara Café, UMT.

\section{Materials and methods}

\subsection{Research design}

This cross-sectional study was conducted in Mutiara Café, Universiti Malaysia Terengganu. The sample size was calculated using Cochran formula at a confidence level of $95 \%$, with $41.25 \%$ of university students having low nutrition knowledge as the proportion, and assuming 10\% attrition. Thus, 108 Mutiara Café customers aged 18 to 59 years old were selected through purposive sampling. Ethical approval was obtained by Universiti Malaysia Terengganu's Human Research Ethics Committees, with the reference number of JKEPM/2019/35.

\subsection{Research instrument}

Nutrilabelapps $\left({ }^{\circledR}\right.$ app and a self-administered questionnaire were used as the instruments in this study. The app has two key functionality specifications: 1) to scan the picture of standard food item provided at Mutiara Café; and 2) provide nutritional information of cooked food (in calorie) consists of energy, carbohydrates, proteins and fats. The bilingual questionnaire was a combination of a self-designed and modified questionnaire from the Malaysia Ministry of Health portal. The final set of the questionnaire consists of five main sections. The socio-demographic section consists of information including gender, age, ethnicity, occupation, level of education, marital status and question of menu labelling usage. The second section was knowledge of nutrition menu labelling among Mutiara Café customer. This section consists of 25 questions which consist of 14 items of recommended nutrient intake (RNI), 4 items of recommended energy intake, 4 items of recommended serving size and 3 items of food group (macronutrient) classification. The scale was treated as nominal data and points were given for each category as follows; 1 -Yes; 0 -No or Not sure. The point total was calculated at the end of the knowledge questionnaire section for each respondent. Scores ranging from $0-13,14-18$, and 19-25 indicated poor, moderate and good levels of knowledge (Remali et al., 2019). The attitude part consists of 12 questions which were developed and modified from several studies (Piron et al., 2010; Song et al., 2015). A five-point Likert-type scale was used to indicate each respondent's level of agreement or disagreement towards attitude on nutrition menu labelling statement (strongly disagree, disagree, not sure, agree, strongly agree) with scores ranging from 12-60. A score of 45 or above indicates a high level of attitude on nutrition menu labelling and a more positive attitude towards menu labelling. A score of less than 45 indicates a low level of attitude on nutrition menu labelling (Marina et al., 2020). The feasibility of the app section consists of 10 self-structured questions adapted from Salihah et al., (2017). The score was rated on five Likert-type scale responses; 1-strongly disagree; 2disagree; 3-not sure; 4-agree; 5-strongly agree. A score of 40 or above indicates that Nutrilabelapps $\subset$ is feasible for the user (Tariman et al., 2011). The acceptability of the app adapted from Salihah et al. (2017) indicates the experience of using Nutrilabelapps $\mathbb{C}$, how enjoyable the application was to use, how helpful the application was, whether the participant enjoyed using the application, whether the participant wished to own the application, and overall satisfaction with the application (Mullen et al., 2004). A score of 40 or above indicates that the Nutrilabelapps $\mathbb{C}$ is acceptable to the user (Tariman et al., 2011). All in all, the questionnaire attained excellent internal consistency reliability for knowledge (0.925), attitude (0.862), feasibility (0.968), and acceptability (0.976). The validity for attitude, feasibility and acceptability was confirmed by convergent validity in which Spearman's correlation coefficients between scales were, on average, low. 


\subsection{Data collection}

Data collection began by inviting the Mutiara Café customer to join the survey. Informed consent was obtained prior to the collection of data. Next, the customer was briefed on the Nutrilabelapps $\mathbb{C}$, focusing on development, special features and key functionality specifications. The customer then scanned the app for about five minutes (depending on the researcher's explanation on how to scan the food and what type of foods were included). After being explained on the app, the customer completed the questionnaire. The customer was assured that their responses would remain confidential and that no personal information would be released in any way. Once the questionnaire was completed, they were given a token as a gift.

\subsection{Data analysis}

All data were analyzed using Statistical Package for the Social Science (SPSS) version 25. The normality test was performed using Kolmogorov-Smirnov. Frequency, percentage, mean score (SD) or median score (IQR) were used to present descriptive data. Spearman correlation's coefficient was applied to determine the relationship between knowledge, attitude, feasibility and acceptability of augmented reality nutrition menu labelling among Mutiara Café customers at $\mathrm{p}<0.05$.

\section{Results and discussions}

\subsection{Socio-demographic profile}

Most of the respondents were UMT students undertaking a degree; female; single; Malay; and with a mean age of 23 years old as stated in Table 1, which also shows that $75 \%$ of the respondents revealed that they knew what nutrition menu labelling was, while $68.5 \%$ customers understand the content in the nutrition menu labelling and $57.4 \%$ agreed that menu labelling influenced their food choice during purchasing. Previous research has established that the nutritional information labels provided influenced customer during decision making (Prinsloo et al., 2012; Latiff et al., 2013; Reale and Flint, 2016). Surprisingly, less than $30 \%$ of the respondents reported reading nutrition menu labelling when they buy or receive food. The remaining revealed that they sometimes and never used nutrition menu labelling. This is similar as reported by Jefrydin et al. (2019) where only about one-fourth of the secondary school adolescents that always read nutrition menu labelling. This indicates that customer always neglected to read nutrition menu labelling during purchasing. The enthralling finding in this study was that nutrition menu labelling information frequently read through by the respondents included only total energy, carbohydrate and fat content, while salt and mineral contents were the most neglected nutrition information as per Table 1 . In this study, about half of Mutiara Café customers agreed they understood the information on the nutrition label.

Table 1. Socio-demographic profile of the respondents $(n=108)$

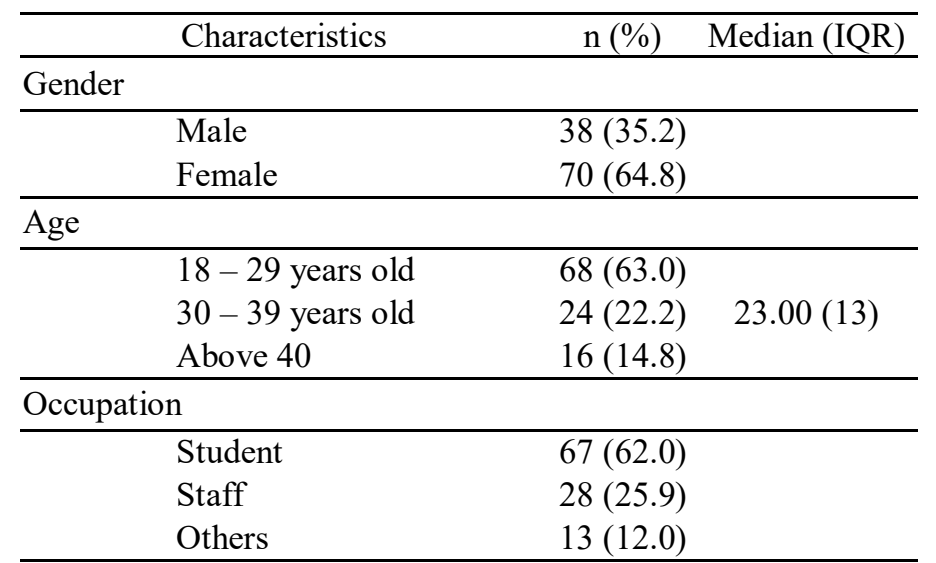

Level of education

\begin{tabular}{llc}
\hline & SPM & $7(6.5)$ \\
& Undertaking Diploma & $10(9.3)$ \\
& Undertaking Degree & $72(66.7)$ \\
& Master/PhD holder & $19(17.5)$ \\
\hline Ethnicity & \\
\hline & Malay & $81(75.0)$ \\
& Chinese & $3(2.8)$ \\
& Indian & $24(22.2)$ \\
\hline
\end{tabular}

\begin{tabular}{cc}
\hline Marital status & \\
\hline Single & $71(65.7)$ \\
Married & $37(34.3)$ \\
\hline
\end{tabular}

Knowledge of nutrition menu labelling

$\begin{array}{ll}\text { Yes } & 81(75.0) \\ \text { No } & 27(25.0)\end{array}$

Knowledge of nutrition menu labelling content

$\begin{array}{ll}\text { Yes } & 74(68.5) \\ \text { No } & 34(31.5)\end{array}$

Nutrition menu labelling influence purchase

$\begin{array}{ll}\text { Yes } & 62(57.4) \\ \text { No } & 46(42.6)\end{array}$

Reading nutrition menu labelling during purchasing

$\begin{array}{lc}\text { Yes } & 31(28.7) \\ \text { Sometimes } & 71(65.7) \\ \text { No } & 6(5.6)\end{array}$

Nutrition menu labelling information that is read through

$\begin{array}{lc}\text { Total energy } & 53(49.1) \\ \text { Carbohydrate content } & 32(29.6) \\ \text { including sugar } & 12(11.1) \\ \text { Fat content } & 0(0.0) \\ \text { Salt or Sodium content } & 3(2.8) \\ \text { Vitamin content } & 0(0.0) \\ \text { Mineral content } & 2(1.9) \\ \text { Food additives } & 1(0.9) \\ \text { Fibre } & 3(2.8) \\ \text { Other } & 2(1.9) \\ \text { None } & \end{array}$

\begin{tabular}{cc}
\hline Understanding of nutrition menu labelling \\
\hline Yes & $56(51.9)$ \\
Sometimes & $45(41.7)$ \\
No & $7(6.5)$ \\
\hline
\end{tabular}




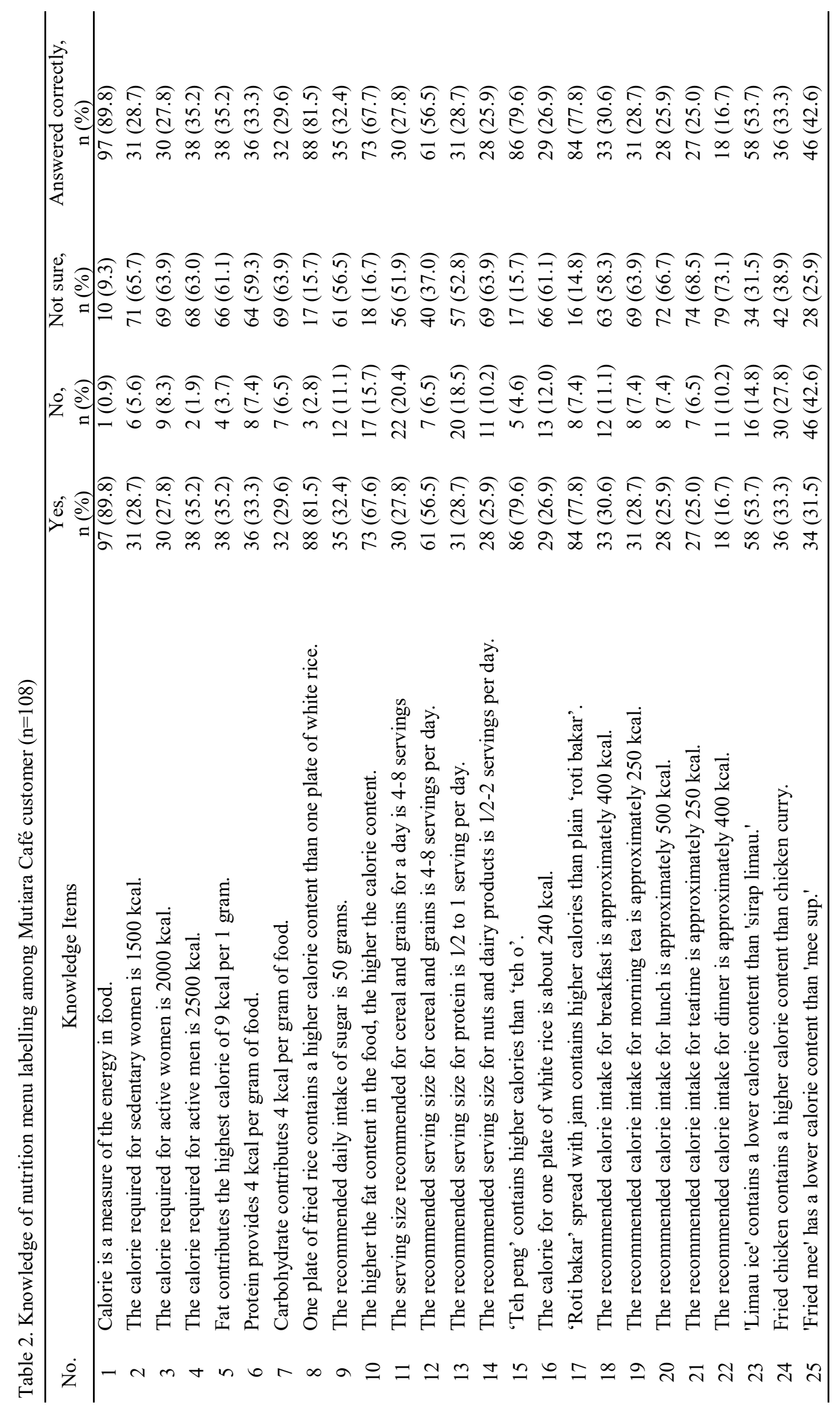


3.2 Knowledge and attitude of nutrition menu labelling among Mutiara Café customer

Referring to Table 2, it was shown that the lowest percentage of respondents answered correctly was item 22 . Only $16.7 \%$ of the respondents answered correctly for item 22 where the recommended calorie intake is concerned. As McCrory et al. (2016) reported, only $24.4 \%$ of participants responded correctly to the recommended daily intake (Breck and Elbel, 2017). On the other hand, food calorie knowledge consists of items $8,10,15,17,23,24$ and 25 , which show that more than 70 per cent responded correctly except for three items (items 23, 24 and 25) which had less than 50 per cent of respondents who were able to respond correctly. This may be due to the difficulty of estimating the calorie in the food listed. In the Calorie Estimate Study on Menu Labeling, Schwartz et al. (2013) stipulated that people had difficulty estimating calories in restaurants. In the meantime, item 1 received the highest percentage of 89.8 per cent, followed by item 15 and item 17 with 77.8 per cent and 79.6 per cent respectively. Overall, most customers were unaware of the nutrition information and recommended daily intake, as knowledge of the nutritional menu labelling was generally poor.

As expected, only $4.6 \%$ of Mutiara Café's customers had a good level of overall knowledge while the remaining had moderate and poor overall knowledge as depicted in Table 3 . This is relatively unexpected as most of the respondents are university students. As stated in the previous study, the relationship between nutritional knowledge and the level of education is directly proportional (Cannoosamy et al., 2014). People with higher education level should have high knowledge of menu labelling (Grunert et al., 2010), but this cannot be seen in the community of Mutiara Café customer. The outcome on Table 3 is contrary to a previous study carried out among university student in Selangor, which stated that $90.3 \%$ had the adequate (high and medium) level of knowledge (Nurliyana et al., 2011) which shows a huge difference among Mutiara Café customers. These findings have important implications for the development of more nutritional menu labelling around the UMT area, in order to increase understanding and raise awareness of the nutritional menu labelling among the UMT community, particularly among students.

Table 4 shows the attitude of Mutiara Café customer towards nutrition menu labelling. Previous studies evaluating attitude towards nutrition menu labelling observed inconsistent results on whether customers had moderate or good attitudes towards menu labelling (Norazlanshah et al., 2013). Per Table 3, the most interesting finding was that $71.3 \%$ of Mutiara Café customer had positive attitudes towards nutrition menu labelling. Only $28.7 \%$ of customers had a negative attitude of nutrition menu labelling which indicate a low level of attitude. This study confirms that attitude of nutrition menu labelling among Mutiara Café customer has expressed a positive attitude on menu labelling (Radwan et al., 2017). These findings are in agreement with Marina's et al. (2020) findings which showed a positive attitude among customers of selected cafes provided with nutrition menu labelling.

Table 3. Classification of knowledge and attitude based on total score $(n=108)$

\begin{tabular}{lcc}
\hline \multicolumn{1}{c}{ Component } & $\mathrm{n}(\%)$ & $\begin{array}{c}\text { Median } \\
(\mathrm{IQR})\end{array}$ \\
\hline Knowledge & $81(75.0)$ & $9.50(7)$ \\
Poor (0 - 13 points) & $22(20.4)$ & \\
Moderate (14 - 18 points) & $5(4.6)$ & \\
$\quad$ High (19 - 25 points) & $31(28.7)$ & \\
Attitude & $77(71.3)$ & \\
$\quad$ Negative (Less than 45) & \\
Positive (45 and above) & & \\
\hline
\end{tabular}

3.3 Feasibility and acceptability of Nutrilabelapps $(\mathbb{C}$ among Mutiara Café customer

Based on Table 5, the most astounding finding was most of the respondents agree and strongly agree with the statement on the feasibility of Nutrilabelapps $\mathbb{C}$. Respondents also agreed that features in Nutrilabelapps $(\mathrm{C}$ is catchy and it grabs their attention. These results reflect study by Yepes (2015) where the participants agreed that the menu application was fun, easy, useful, convenient and not difficult or time-consuming. As the participant accepted the implementation of menu labels application, Yepes (2015) suggested for the usage of mobile tablets application in restaurants for market differentiation, also to attract new customer and increase the number of customers. This overwhelming response may be due to the attraction of Nutrilabelapps $\mathbb{C}$ as a new intervention implemented in UMT café. In this era, there are several mobile food deliveries such as Food Panda, Grab Food, and Bungkusit. The application will show up a list of menus for selected restaurants or café. However, there is no calorie stated for each food in the menu list. This is why Nutrilabelapps $(\mathbb{C}$ intervention was done, besides from introducing a new virtual application related to menu labelling, it also increased awareness among customer on nutrition menu labelling and following the fourth industrial revolution (IR 4.0).

According to Table 6, most of the Mutiara Café customer accept the application existence. Yet, only $0.9 \%$ of Mutiara Café customer strongly agreed that Nutrilabelapps $\bigcirc$ will help to increase nutrition knowledge of menu labelling. However, the findings of the current study do not support previous research in which all respondents $(100 \%)$ agreed that Candi $^{\mathrm{TM}}$ 


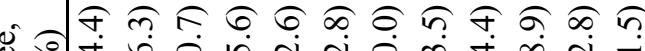

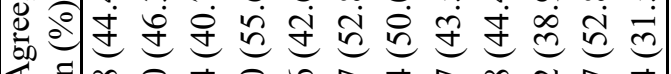

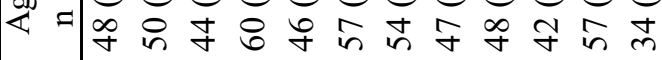

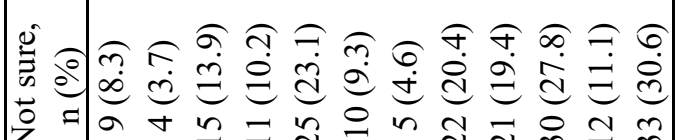

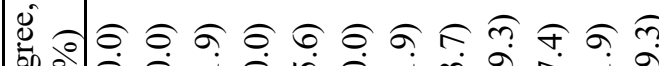

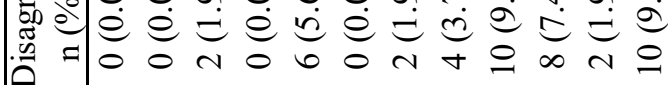

๙ิ :

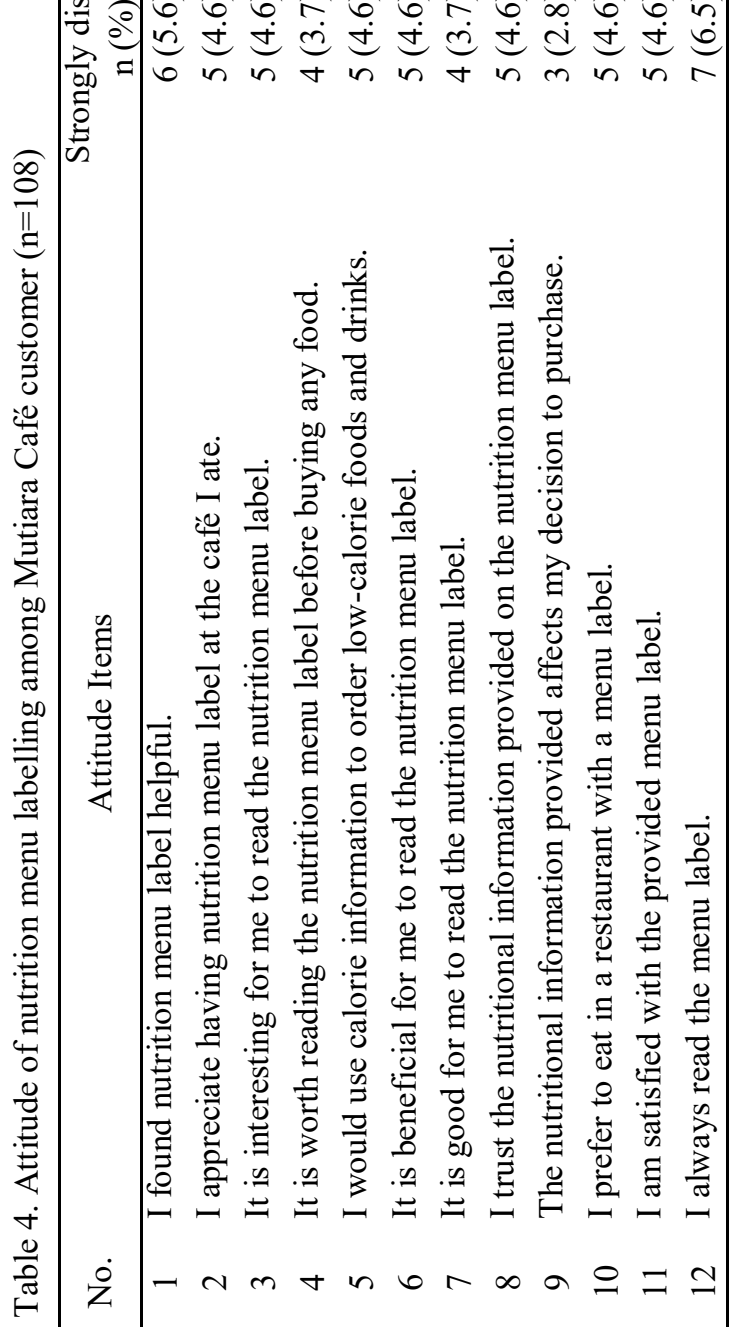

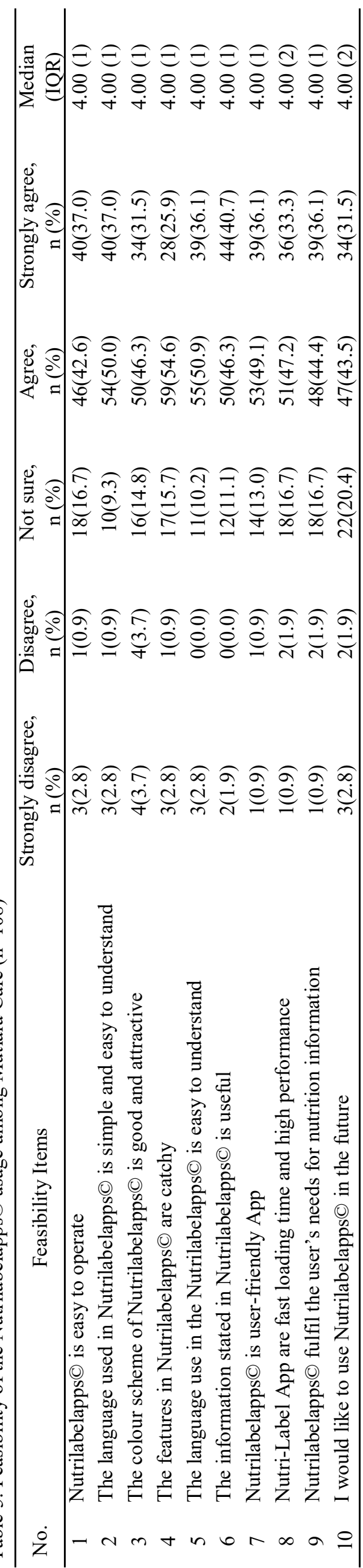

C 2020 The Authors. Published by Rynnye Lyan Resources 


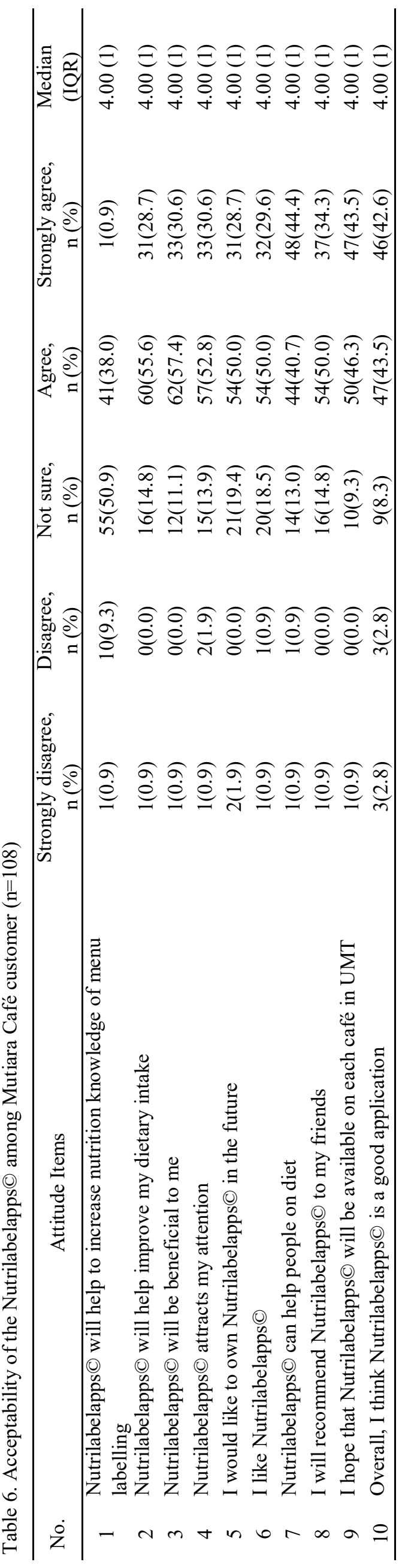


application would help the user to improve their nutrition knowledge (Salihah et al., 2017). Table 6 shows that more than half respondents agreed Nutrilabelapps@ $($ will help them to improve their dietary intake because Nutrilabelapps $@$ show up the energy in calorie for each food at Mutiara Café. These results are in line with previous studies where it showed that application implemented was effective for menu labelling learning and the application might help customer to control the daily food intake (Juan et al., 2019). About 19.4\% of Mutiara Café customer was not sure on whether they will own Nutrilabelapps $(\subset$ or not as they were unwilling to explore new things. In contrast, $44.4 \%$ respondents strongly agreed that Nutrilabelapps $₫$ will help people who are on a diet as this application can be tools for them to control their calorie daily intake as most of the people admit that application related to health is reliable and need to be developed more to help people in daily life activities such as exercise, diet, calorie counting and BMI (Payne et al., 2012). These findings are in line with a previous study where most of the user would use the application if it were available on each café in UMT and found Nutrilabelapps $\subset$ is a good application overall.

As illustrated in Table 7, the overwhelmingly positive feedback was received as the majority of Mutiara Café customers agreed to accept the application at $67.6 \%$ and $75.9 \%$ in terms of feasibility and acceptability rate. A study stated the acceptance measurement by users can be used in research or clinical practice to evaluate acceptability and usability of computer-based assessment (Tariman et al., 2011). It could say that Mutiara Café customer does accept the existence of Nutrilabelapps $\bigcirc$ as a new intervention. But, studies in the intervention of application related to nutrition menu labelling need to be increased as for now only application regarding diet-related disease has been implemented in Malaysia.

As expected, this study has been able to demonstrate significant relationships among knowledge, attitude, feasibility and acceptability of augmented reality nutrition menu labelling application usage among
Mutiara Café customers as can be seen in Table 8. The finding showed that feasibility and acceptability of Nutrilabelapps $(\mathbb{C}$ are linked, as most of Mutiara Café's customers agreed with the implemented of Nutrilabelapps $\bigcirc$ at Mutiara Café as a new intervention.

Table 7. Classification of feasibility and acceptability based on total score $(\mathrm{n}=108)$

\begin{tabular}{lcc}
\hline \multicolumn{1}{c}{ Component } & $\begin{array}{c}\text { Frequency } \\
\mathrm{n}(\%)\end{array}$ & $\begin{array}{c}\text { Median } \\
(\mathrm{IQR})\end{array}$ \\
\hline $\begin{array}{l}\text { a Feasibility } \\
\text { Unacceptable by user (Less } \\
\text { than 40 points) }\end{array}$ & $35(32.4)$ & $40.00(9)$ \\
$\begin{array}{l}\text { Acceptable by user (40 points } \\
\text { and above) }\end{array}$ & $73(67.6)$ & \\
${ }^{\mathbf{b}} \begin{array}{l}\text { Acceptability } \\
\text { Unacceptable by user (Less }\end{array}$ & $26(24.1)$ & \\
than 40 points) & & \\
$\begin{array}{l}\text { Acceptable by user (40 points } \\
\text { and above) }\end{array}$ & $82(75.9)$ & \\
\hline
\end{tabular}

${ }^{a}$ Acceptability $($ minimum $=10$, maximum $=50)$

${ }^{\mathrm{b}}$ Feasibility $($ minimum $=10$, maximum $=50)$

\section{Conclusion}

This study provides better insight into the relationships between knowledge, attitude, feasibility and acceptability towards nutrition menu labelling among Mutiara Café customer. This study has identified Mutiara Café's customers had poor knowledge but a positive attitude towards nutrition menu labelling. The application of Nutrilabelapps $(\subset$ has been accepted by Mutiara Café's customers, as they agreed on the feasibility and acceptability of augmented reality nutrition menu labelling application. Mutiara Café's customers demonstrated the significant relationships between knowledge, attitude, feasibility and acceptability on augmented reality nutrition menu labelling application. However, there were several limitations in this study which the findings cannot be generalized to all café's customers, as the data was derived from Mutiara Café customers only. The age of the respondents should be increased to establish significance association between knowledge and attitude,

Table 8. Relationship between knowledge, attitude, feasibility and acceptability of augmented reality nutrition menu labelling among Mutiara Café customer $(n=108)$

\begin{tabular}{llcccc}
\hline & & Knowledge & Attitude & Feasibility & Acceptability \\
\hline Knowledge & Correlation Coefficient & 1 & $0.370^{*}$ & $0.334^{*}$ & $0.329^{*}$ \\
& p-value & & 0.00 & 0.00 & 0.00 \\
\hline Attitude & Correlation Coefficient & $0.370^{*}$ & 1 & $0.655^{*}$ & $0.545^{*}$ \\
& $p$-value & 0.00 & & 0.00 & 0.00 \\
\hline Feasibility & Correlation Coefficient & $0.334^{*}$ & $0.655^{*}$ & 1 & $0.723^{*}$ \\
& p-value & 0.00 & 0.00 & & 0.00 \\
\hline Acceptability & Correlation Coefficient & $0.329^{*}$ & $0.545^{*}$ & $0.723^{*}$ & 1 \\
& p-value & 0.00 & 0.00 & 0.00 & \\
\hline
\end{tabular}

*significant at $\mathrm{p}<0.05$ 
feasibility, acceptability on augmented reality nutrition menu labelling application among Mutiara Café customer. Further work is imperative to determine whether there are any similarities between the findings.

\section{Conflict of interest}

The authors declare no conflict of interest.

\section{Acknowledgements}

The authors thank all the respondents for their participation, full cooperation, and patience in completing the study. The authors also like to extend their gratitude to Mr. Za'ba bin Tamammodin, owner of Mutiara Café. This study was funded under the Universiti Malaysia Terengganu (UMT)'s Knowledge and Technology Assimilation Grant (KTAG 2018) scheme.

\section{References}

Breck, A. and Elbel, B. (2017). Knowledge of Recommended Daily Caloric Intake Among Fast Food Customers. SSRN Electronic Journal, 2017, 3001393. https://doi.org/10.2139/ssrn.3001393

Cannoosamy, K., Pugo-gunsam, P. and Jeewon, R. (2014). Customer Knowledge and Attitudes Toward Nutritional Labels. Journal of Nutrition Education and Behavior, 4(5), 334-340. https://doi.org/10.1016/ j.jneb.2014.03.010

Department of Statistics, Malaysia. (2015). Report on household expenditure survey: Malaysia 2014. Putrajaya, Malaysia: Percetakan National Berhad.

Grunert, K.G., Wills, J.M. and Fernández-Celemín, L. (2010). Nutrition knowledge, and use and understanding of nutrition information on food labels among customers in the UK. Appetite, 55(2), 177189. https://doi.org/10.1016/j.appet.2010.05.045

Jefrydin, N., Nor, N.M. and Talib, R.A. (2019). Nutrition labelling: An exploratory study on personal factors that influence the practice of reading nutrition labels among adolescents. Malaysian Journal of Nutrition, 25(1), 143-154. https://doi.org/10.31246/mjn-20180123

Juan, M.-C., Charco, J.L., García-García, I. and Mollá, R. (2019). An Augmented Reality App to Learn to Interpret the Nutritional Information on Labels of Real Packaged Foods. Frontiers in Computer Science, 2019, 00001. https://doi.org/10.3389/ fcomp.2019.00001

Kerins, C., Cunningham, K., Finucane, F. M., Gibson, I., Jones, J. and Kelly, C. (2016). Effects of an iconbased menu labelling initiative on customer food choice. Perspectives in Public Health, 137(1), 4552. https://doi.org/10.1177/1757913916640826

Latiff, Z.A.A., Mohamed, Z.A., Rezai, G. and Kamaruzzaman, N.H. (2013). The Impact of Food Labeling on Purchasing Behavior Among NonMuslim Customers in Klang Valley. Australian Journal of Basic and Applied Sciences, 7(1), 124128.

Marina, M., Asma', A., Jaafar, S.N.A., Abdul Wahab, M.R. and Wan Zainal Shukri, W.H. (2020). Nutrition menu labelling in Terengganu: a cross-sectional study of knowledge, attitudes, perception and their relationship with healthy food choices. Food research, 4(5), 1573-1581. https://doi.org/10.26656/ fr.2017.4(5).138

McCrory, C., Vanderlee, L., White, C.M., Reid, J.L. and Hammond, D. (2016). Knowledge of Recommended Calorie Intake and Influence of Calories on Food Selection Among Canadians. Journal of Nutrition Education and Behavior, 48(3), 199-207.e1. https:// doi.org/10.1016/j.jneb.2015.12.012

Insitute for Public Health. (2017). National Health and Morbidity survey (NHMS) 2017: Key Findings from the Adolescent Health and Nutrition Surveys. Kuala Lumpur, Malaysia: Institue for Public Health, National Institutes of Health, Ministry of Health Malaysia.

Mullen, K.H., Berry, D.L. and Zierler, B.K. (2004). Computerized symptom and quality-of-life assessment for patients with cancer part II: acceptability and usability. Oncology Nursing Forum, 31(5), E84-E89. https:// doi.org/10.1188/04.ONF.E84-E89

Norazlanshah, H., Muhammad, I., Hasmira, M.D., Mashita, M., Norfazlila, M.R. and Fazlyla, N. M.F. (2013). The Use of Nutrition Label on Food Purchasing Decision among University Students in Kuantan, Malaysia. Health and the Environmental Journal, 4(1), 1-10.

Nurliyana, G., Norazmir, M.N. and Anuar, M.I.K. (2011). Knowledge, Attitude and Practices of University Students Regarding the Use of Nutritional Information and Food Labels. Asian Journal of Clinical Nutrition, 3(3), 79-91. https:// doi.org/10.3923/ajen.2011.79.91

Payne, K.F.B., Wharrad, H. and Watts, K. (2012). Smartphone and medical related App use among medical students and junior doctors in the United Kingdom (UK): A regional survey. BMC Medical Informatics and Decision Making, 12, 121. https:// doi.org/10.1186/1472-6947-12-121

Piron, J., Smith, L.V., Simon, P., Cummings, P.L. and 
Kuo, T. (2010). Knowledge, attitudes and potential response to menu labelling in an urban public health clinic population. Public Health Nutrition, 13(4), 550-555. https://doi.org/10.1017/ S1368980009991303

Prinsloo, N., Merwe, D., Van Der Bosman, M. and Erasmus, A. (2012). A Critical Review Of The Significance Of Food Labelling During Customer Decision Making. Journal of Consumer Sciences, 40, 83-98.

Radwan, H., Faroukh, E.M. and Obaid, R.S. (2017). Menu labeling implementation in dine-in restaurants: The Public's knowledge, attitude and practices. Archives of Public Health, 75(1), 1-7. https:// doi.org/10.1186/s13690-017-0177-9

Reale, S. and Flint, S.W. (2016). Menu labelling and food choice in obese adults: A feasibility study. BMC Obesity, 3, 17. https://doi.org/10.1186/S40608016-0095-3

Remali, R., Ali, A., Zakaria, N.S. and Yusof, H.M. (2019). Assessing knowledge, attitude, practice towards type ii diabetes mellitus and their blood glucose level among public in selected areas of Bachok district, Kelantan. Malaysian Applied Biology, 48(1), 145-155.

Salihah, N., Lua, P.L., Ahmad, A. and Nerus, K. (2017). "Candi" TM": A Malaysian-Tailored Dietary Smartphone App For Cancer Patients And Survivors. Malaysian Journal of Public Health Medicine, Special Volume(2), 32-40.

Schwartz, M.B., Brownell, K.D. and White, M.A. (2013). Calorie estimation accuracy and menu labeling perceptions among individuals with and without binge eating and/or purging disorders. Eating and Weight Disorders - Studies on Anorexia, Bulimia and Obesity, 18, 255-261. https:// doi.org/10.1007/s40519-013-0035-x

Song, J., Huang, J., Chen, Y., Zhu, Y., Li, H., Wen, Y., Yuan, H. and Liang, Y. (2015). The understanding, attitude and use of nutrition label among customers (China) | El conocimiento, la actitud y el uso de la etiqueta nutricional entre los consumidores (China). Nutricion Hospitalaria, 31(6), 2703-2710. https:// doi.org/10.3305/nh.2015.31.6.8791

Tariman, J.D., Berry, D.L., Halpenny, B., Wolpin, S. and Schepp, K. (2011). Validation and testing of the Acceptability E-scale for Web-based patientreported outcomes in cancer care. Applied Nursing Research, 24(1), 53-58. https://doi.org/10.1016/ j.apnr.2009.04.003

van der Laan, L.N., de Ridder, D.T.D., Viergever, M.A. and Smeets, P.A.M. (2012). Appearance matters:
Neural correlates of food choice and packaging aesthetics. PLoS ONE, 7(7), 0041738. https:// doi.org/10.1371/journal.pone.0041738

Vanderlee, L., White, C.M. and Hammond, D. (2019). Evaluation of a voluntary nutritional information program versus calorie labelling on menus in Canadian restaurants: A quasi-experimental study design. International Journal of Behavioral Nutrition and Physical Activity, 16(1), 1-10. https:// doi.org/10.1186/s12966-019-0854-x

Yepes, M.F. (2015). Mobile Tablet Menus: Attractiveness and Impact of Nutrition Labeling Formats on Millennials' Food Choices. Cornell Hospitality Quarterly, 56(1), 58-67. https:// doi.org/10.1177/1938965514546371 